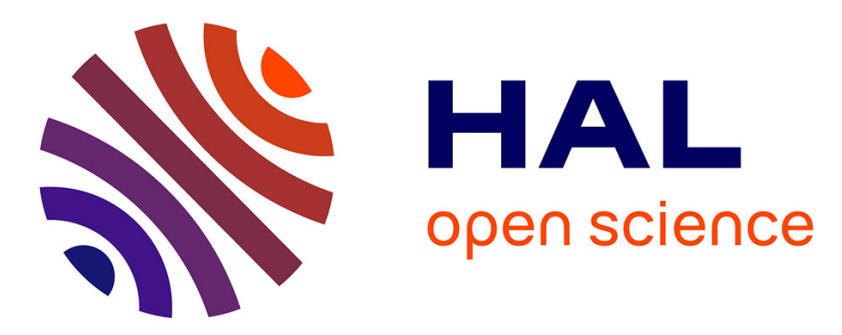

\title{
INFLUENCE OF ETCHING THE TiC UNDERLAYER WITH CH4/AlCl3/H2 ON THE CVD FORMATION OF KAPPA-A12O3
}

\author{
M. Danzinger, R. Haubner, B. Lux
}

\section{- To cite this version:}

M. Danzinger, R. Haubner, B. Lux. INFLUENCE OF ETCHING THE TiC UNDERLAYER WITH CH4/AlCl3/H2 ON THE CVD FORMATION OF KAPPA-Al2O3. Journal de Physique IV Proceedings, 1991, 02 (C2), pp.C2-579-C2-586. 10.1051/jp4:1991269 . jpa-00249859

HAL Id: jpa-00249859

https://hal.science/jpa-00249859

Submitted on 1 Jan 1991

HAL is a multi-disciplinary open access archive for the deposit and dissemination of scientific research documents, whether they are published or not. The documents may come from teaching and research institutions in France or abroad, or from public or private research centers.
L'archive ouverte pluridisciplinaire HAL, est destinée au dépôt et à la diffusion de documents scientifiques de niveau recherche, publiés ou non, émanant des établissements d'enseignement et de recherche français ou étrangers, des laboratoires publics ou privés. 
Colloque C2, suppl. au Journal de Physique II, Vol. 1, septembre 1991

\title{
INFLUENCE OF ETCHING THE TIC UNDERLAYER WITH $\mathrm{CH}_{4} / \mathrm{AlCl}_{3} / \mathrm{H}_{2}$ ON THE CVD FORMATION OF KAPPA-A1 $\mathrm{O}_{3}$
}

M. DANZINGER, R. HAUBNER and B. LUX

Institute for Chemical Technology of Inorganic Materials, Technical University Vienna, A-1060 Vienna, Austria

\begin{abstract}
Al}_{2} \mathrm{O}_{3}$ coatings deposited by CVD on cemented carbide inserts precoated with TiC did not lead to kappa- $\mathrm{Al}_{2} \mathrm{O}_{3}$ formation under laboratory conditions. An "etching treatment" with $\mathrm{CH}_{4} / \mathrm{AlCl}_{3} / \mathrm{H}_{2}$ gas mixtures prior to $\mathrm{Al}_{2} \mathrm{O}_{3}$ deposition did however promote kappa- $\mathrm{Al}_{2} \mathrm{O}_{3}$ growth. A pronounced dependence of the amount of kappa- $\mathrm{Al}_{2} \mathrm{O}_{3}$ on the etching time and on the $\mathrm{CH}_{4}$ concentration during the etching procedure was observed. $A$ decrease in the deposition temperature increased the amount of the kappa- $\mathrm{Al}_{2} \mathrm{O}_{3}$. The alpha:kappa- $\mathrm{Al}_{2} \mathrm{O}_{3}$ ratio was also influenced by the co content in the cemented carbide inserts. Higher percentages of kappa-Al $\mathrm{O}_{3}$ were observed for inserts with the lower Co concentrations than with the higher co concentrations. However, no kappa-Al $\mathrm{O}_{3}$ was deposited when $\mathrm{CH}_{4}$ was added during $\mathrm{Al}_{2} \mathrm{O}_{3}$ deposition. Only the pure and undoped $\mathrm{AlCl} \mathrm{C}_{3} / \mathrm{CO}_{2} / \mathrm{H}_{2}$ system led to the kappa- $\mathrm{Al}_{2} \mathrm{O}_{3}$ formation.
\end{abstract}

\section{INIRODUCTION}

Aluminum oxide exhibits different allotropic modifications $11 /$. Around $1000^{\circ} \mathrm{C}$ the alpha-modification is the stable phase, the second most commonly occurring phase is kappa- $\mathrm{Al}_{2} \mathrm{O}_{3}$, which is less stable than the alpha phase. At temperatures above $1000^{\circ} \mathrm{C}$, kappa-Al $\mathrm{O}_{3}$ transforms to the alpha modification $/ 2-5 /$.

Recent TEM investigations by c.Chatfield $/ 5 /$ showed an epitaxial relationship between TiC and kappa- $\mathrm{Al}_{2} \mathrm{O}_{3}$, which is supposed to improve the coating adhesion. Furthermore kappa- $\mathrm{Al}_{2} \mathrm{O}_{3}$ has a finer grain structure than the alpha-modification $/ 3,7 /$. Kappa-Al ${ }_{2} \mathrm{O}_{3}$ formation and epitaxy occurred only on a clean, unoxidized Tic underlayer. If $\mathrm{Ti}_{2} \mathrm{O}_{3}$ or $\mathrm{Ti}_{3} \mathrm{O}_{5}$ was present, only the alpha-Al $\mathrm{O}_{2} \mathrm{O}_{3}$ phase was obtained, and no epitaxy could be found in this case $/ 5 /$.

$\mathrm{CH}_{4}$ addition in an $\mathrm{AlCl}_{3} / \mathrm{H}_{2} / \mathrm{CO}_{2}$ environment stabilized the $\mathrm{kappa}-\mathrm{Al}_{2} \mathrm{O}_{3}$ $16 \%$, which was deposited on a WC-Co substrate even without a TiC underlayer. Other investigations showed that Co, which is usually unevenly distributed over the TiC surface, acts as a catalyst for the heterogeneous decomposition of $\mathrm{CO}_{2}$ to $\mathrm{CO}$ and monoatomic oxygen. This monoatomic oxygen can be responsible for the oxidation of Tic $/ 5 /$. Also substrates, which were exposed to normal air and humidity for weeks oxidize. on such substrates under laboratory conditions always alpha- $\mathrm{Al}_{2} \mathrm{O}_{3}$ was obtained but never kappa-Al $\mathrm{O}_{3} / 6,8 \%$. 
The purpose of the present work was to study the influence of an "etching treatment" with $\mathrm{AlCl}_{3} / \mathrm{H}_{2} / \mathrm{CH}_{4}$ gas mixtures, prior to the $\mathrm{Al}_{2} \mathrm{O}_{3}$ deposition, of the oxidized TiC underlayers on the formation of kappa$\mathrm{Al}_{2} \mathrm{O}_{3}$

\section{EXPERIMENTAL PROCEDURE}

Both etching treatment of the TiC underlayers and the $\mathrm{Al}_{2} \mathrm{O}_{3}$ deposition were carried out in a hot-wall CVD reactor as described elsewhere $/ 6 /$. The $\mathrm{AlCl}_{3} / \mathrm{CO}_{2} / \mathrm{H}_{2}$ system was used for the $\mathrm{Al}_{2} \mathrm{O}_{3}$ deposition.

The substrates used were:

- SPUN GC $1025^{*}: 76 \%$ WC, $15 \%$ (Nb, Ta,Ti)C, 8,5\% Co

$8 \mu \mathrm{m}$ CVD-TiC; denoted "WC 8,5\% Co"

- SPKN 1203 ED R* $92 \%$ WC, $2 \%(\mathrm{Nb}, \mathrm{Ta}) \mathrm{C}, 6 \% \mathrm{Co}$

*: Grade SANDVIK COROMANT

2.1 Etching procedure for the Tic underlayers

Different gas flow sequences were studied (Fig. 1). These gas flow cycles and the parameters were varied as summarized in Table 1 and Fig.1.

Table 1: Investigated parameters of the predeposition etching treatment of TiC layers with $\mathrm{AlCl}_{3} / \mathrm{H}_{2} / \mathrm{CH}_{4}$ gas mixtures

\begin{tabular}{|c|c|c|}
\hline gas flow cycles & TiC etching & $\mathrm{Al}_{2} \mathrm{O}_{3}$ deposition gas \\
\hline $\begin{array}{l}1 \\
2 \\
3\end{array}$ & $\begin{array}{l}\text { no treatment } \\
\text { AlCl } 3 / \mathrm{CH}_{4} / \mathrm{H}_{2} \\
\text { AlCl } 3 / \mathrm{CH}_{4} / \mathrm{H}_{2}\end{array}$ & 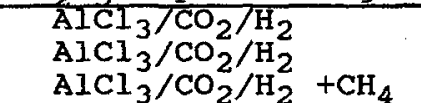 \\
\hline
\end{tabular}

Investigated etching parameters:

$\mathrm{CH}_{4}$ concentration: 3,6 mol\%

Gas phase: 2 mol\% $\mathrm{AlCl}_{3} ; 94 \mathrm{~mol} \% \mathrm{H}_{2}$

Etching time: $1,3,5,7,10 \mathrm{~min}$

Etching temperature: $950,1030^{\circ} \mathrm{C}$

Co concentrations of the: $6,8.5 \%$ substrates

\section{$2.2 \mathrm{Al}_{2} \mathrm{O}_{3}$ deposition}

For the $\mathrm{Al}_{2} \mathrm{O}_{3}$ deposition following the $\mathrm{Tic}$ etching treatment, the parameters listed in Table 2, were kept constant.

Table 2: Constant $\mathrm{Al}_{2} \mathrm{O}_{3}$ deposition parameters

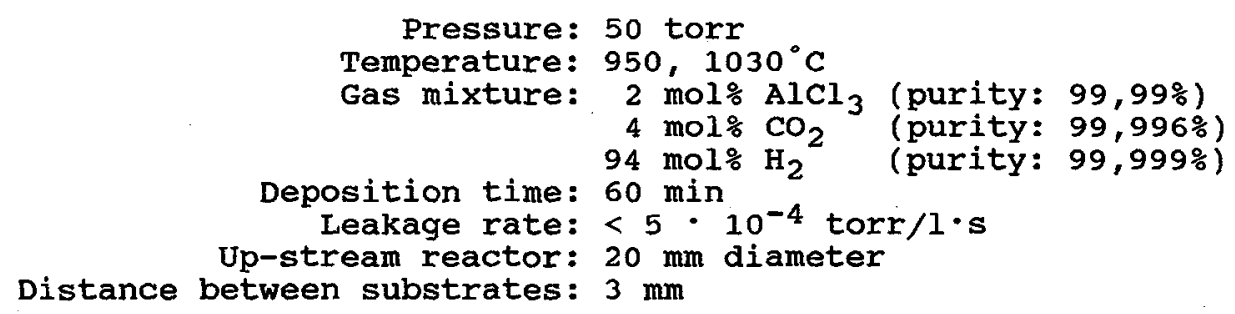


2.3 Characterization of the $\mathrm{Al}_{2} \mathrm{O}_{3}$ coatings Growth rates were calculated from the measured before and after deposition).

$\mathrm{Al}_{2} \underline{\mathrm{O}}_{3}$ modification was determined by $\mathrm{X}$-Ray diffraction.

Al 2 morphology and grain size were examined by SEM without sputtering a thin gold layer. This procedure allowed the identification of differences in contrast, which are characteristic for the alpha(white) and kappa (dark) $\mathrm{Al}_{2} \mathrm{O}_{3} / 7 /$.

The incorporation of impurities, e.g. solid carbon, in the $\mathrm{Al}_{2} \mathrm{O}_{3}$ coatings can also lead to changes in the electrical conductivity and therefore misleadingly simulate alpha- and kappa- $\mathrm{Al}_{2} \mathrm{O}_{3}$. In such cases only $\mathrm{X}$-Ray diffraction clearly indicates the true $\mathrm{Al}_{2} \mathrm{O}_{3}$ modifications present.

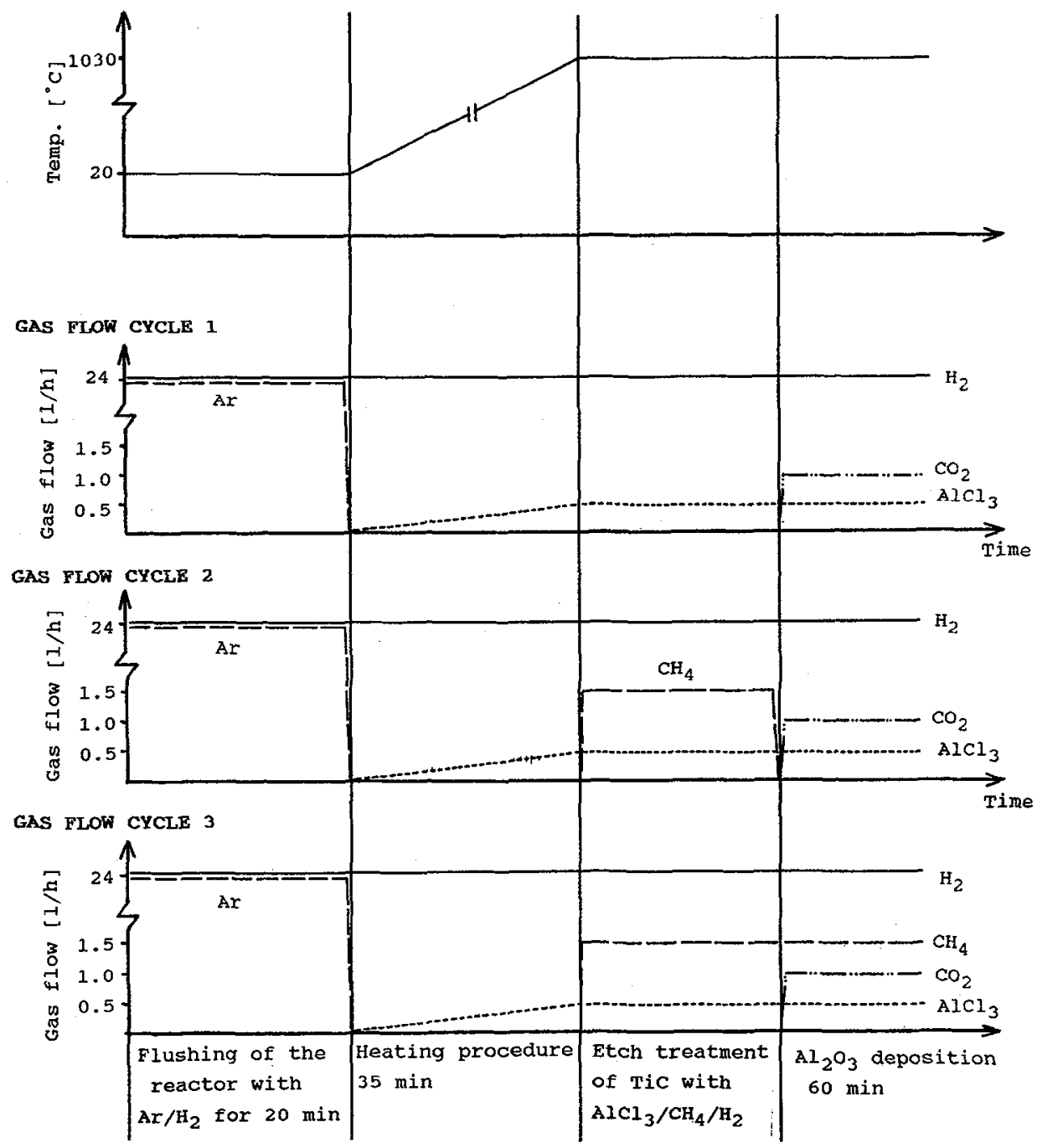

Fig.1: Schematic illustration of the investigated gas flow cycles of the TiC etching treatment and $\mathrm{Al}_{2} \mathrm{O}_{3}$ deposition 


\section{RESULTS OF THE A1 ${ }_{2} \underline{O}_{3}$ DEPOSITION}

3.1 Normal $\mathrm{Al}_{2} \mathrm{O}_{3}$ deposition on a TiC underlayer: gas flow cycle 1 $\mathrm{Al}_{2} \mathrm{O}_{3}$ coatings deposited by gas flow cycle 1 always consisted of pure alpha- $\mathrm{Al}_{2} \mathrm{O}_{3}$ and were used as reference samples. These coatings were uniform and the sizes of well facetted crystals were in the range of $0.5-3.0 \mu \mathrm{m}$.

\section{$3.2 \mathrm{CH}_{4}$ treatment of the TiC prior to the $\mathrm{Al}_{2} \underline{\mathrm{O}}_{3}$ deposition} without $\mathrm{CH}_{4}$ during $\mathrm{Al}_{2} \mathrm{O}_{3}$ deposition: gas fiow cycle 2

\section{- temperature: $950^{\circ} \mathrm{C}$}

No influence on the $\mathrm{Al}_{2} \mathrm{O}_{3}$ growth rates was observed for either of the investigated substrates (Table 3 ). Kappa-Al ${ }_{2} \mathrm{O}_{3}$ was deposited only after etching the TiC underlayers with 6 vol\% $\mathrm{CH}_{4}$ for $1 \mathrm{~min}$. The Co content of the substrates strongly influenced the alpha:kappa ratio. On the substrates with $6 \%$ Co the kappa-Al $\mathrm{O}_{3}$ percentage was $100 \%$, on the substrates with $8.5 \%$ Co it was about $24 \%$ (Table 3, Fig.2). - temperature: $1030^{\circ} \mathrm{C}$

The TiC underlayers etched at $1030^{\circ} \mathrm{C}$ for 1 to $7 \mathrm{~min}$ showed no changes in the $\mathrm{Al}_{2} \mathrm{O}_{3}$ growth rates; a decrease occurred on those etched for 10 $\min (\mathrm{Table} 4)$.

Kappa-Al $\mathrm{O}_{3}$ was deposited only after etching the TiC layers for $5 \mathrm{~min}$ with $3 \mathrm{CH}_{4}$ at $1030^{\circ} \mathrm{C}$ (Fig.3). All the other investigated etching parameters led to the formation of alpha-Al $\mathrm{O}_{3}$ (Table 4). This can be explained by the influence of the deposited carbon on the TiC underlayer and by Co removal due to the formation of volatile $\mathrm{CoCl}_{2}$. In all experiments compact and uniform $\mathrm{Al}_{2} \mathrm{O}_{3}$ coatings, consisting of well facetted crystals, were observed. The grain sizes (range of $0.5-$ $3.0 \mu \mathrm{m})$ are the same as those in the coatings deposited without a TiC etching treatment (gas flow cycle 1 ).

Table 3: Tic etch treatment: $\mathrm{Al}_{2} \mathrm{O}_{3}$ modification and growth rate no $\mathrm{CH}_{4}$ during $\mathrm{Al}_{2} \mathrm{O}_{3}$ deposition: gas flow cycle 2 substrate: WC $6 \%{ }^{\circ} \mathrm{Co}$; WC $8.5 \% \mathrm{Co} ; \mathrm{T}=950^{\circ} \mathrm{C}$;

\begin{tabular}{|c|c|c|c|c|}
\hline \multicolumn{2}{|c|}{$\begin{array}{l}\text { Tic etch treatment } \\
\mathrm{CH}_{4}[\text { mol } \%] \text { time[min] }\end{array}$} & $\begin{array}{l}\text { growth rate } \\
{[\mu \mathrm{m} / \mathrm{h}]}\end{array}$ & \multicolumn{2}{|c|}{$\begin{array}{l}\mathrm{Al}_{2} \mathrm{O}_{3} \text { modification } \\
\text { alpha / kappa [\%] }\end{array}$} \\
\hline \multicolumn{2}{|c|}{ substrate:WC $6 \%$ co } & & & \\
\hline 3 & 3 & $1.0 \pm 0.0$ & 100 & 0 \\
\hline $\begin{array}{l}3 \\
6\end{array}$ & $\begin{array}{l}7 \\
1\end{array}$ & $\begin{array}{l}1.0 \pm 0.0 \\
1.1 \pm 0.0\end{array}$ & $\begin{array}{r}100 \\
0\end{array}$ & $\begin{array}{r}0 \\
100\end{array}$ \\
\hline \multirow{2}{*}{\multicolumn{2}{|c|}{ Substrate: WC $8,5 \%$ Co }} & & & \\
\hline & & $1.05 \pm 0.05$ & 100 & 0 \\
\hline 3 & 7 & $1.0 \pm 0.0$ & 100 & 0 \\
\hline 6 & 1 & $1.15 \pm 0.05$ & 76 & 24 \\
\hline
\end{tabular}

Table 4: Tic etching treatment: $\mathrm{Al}_{2} \mathrm{O}_{3}$ modification and growth rate no $\mathrm{CH}_{4}$ during $\mathrm{Al}_{2} \mathrm{O}_{3}$ deposition: gas flow cycle 2 substrate: $W \mathrm{C} 8.5$ \% $\mathrm{CO} ; \mathrm{T}=1030^{\circ} \mathrm{C}$

\begin{tabular}{|c|c|c|c|c|}
\hline $\begin{array}{l}\text { Tic etch } \\
\mathrm{CH}_{4}[\mathrm{~mol} \%]\end{array}$ & $\begin{array}{l}\text { reatment } \\
\text { time[min] }\end{array}$ & $\begin{array}{c}\text { growth rate } \\
{[\mu \mathrm{m} / \mathrm{h}]}\end{array}$ & $\begin{array}{r}\mathrm{Al}_{2} \mathrm{O}_{3} \mathrm{~m} \\
\quad \mathrm{al} \text { pha }\end{array}$ & $\begin{array}{l}\text { lification } \\
\text { kappa [\%] }\end{array}$ \\
\hline 3 & 1 & $1.65 \pm 0.05$ & 100 & 0 \\
\hline 3 & 3 & $1.55 \pm 0.05$ & 100 & 0 \\
\hline 3 & 5 & $1.6 \pm 0.0$ & 58 & 42 \\
\hline 3 & 7 & $1.65 \pm 0.05$ & 100 & 0 \\
\hline 3 & 10 & $0.75 \pm 0.05$ & 100 & 0 \\
\hline 6 & 1 & $1.65 \pm 0.05$ & 100 & 0 \\
\hline 6 & 3 & $1.65 \pm 0.05$ & 100 & 0 \\
\hline 6 & 10 & $0.6 \pm 0.05$ & 100 & 0 \\
\hline
\end{tabular}




\section{$3.3 \mathrm{CH}_{4}$ treatment of the TiC prior to the $\mathrm{Al}_{2} \mathrm{O}_{3}$ deposition} with $\mathrm{CH}_{4}$ during $\mathrm{Al}_{2} \underline{\mathrm{O}}_{3}$ deposition: gas flow cycle 3

The etching parameters and the addition of 3 and $6 \% \mathrm{CH}_{4}$ during $\mathrm{Al}_{2} \mathrm{O}_{3}$ deposition led to a strong decrease in the $\mathrm{Al}_{2} \mathrm{O}_{3}$ growth rate (Table5). In the investigated range the addition of $\mathrm{CH}_{4}$ during the $\mathrm{Al}_{2} \mathrm{O}_{3}$ deposition led to the formation of alpha- $\mathrm{Al}_{2} \mathrm{O}_{3}$ only. No kappa-Al $\mathrm{O}_{3}$ was detected (Table 5).

Table 5: Influence of the TiC etch treatment and $\mathrm{CH}_{4}$ addition during $\mathrm{Al}_{2} \mathrm{O}_{3}$ deposition on the $\mathrm{Al}_{2} \mathrm{O}_{3}$ modification and growth rate: gas flow cycle 3 ; substrate: $\mathrm{WC} 8.5 \% \mathrm{Co}$; $\mathrm{T}=1030^{\circ} \mathrm{C}$;

\begin{tabular}{|c|c|c|c|c|c|}
\hline \multicolumn{2}{|c|}{ Tic etch treatment } & \multicolumn{3}{|c|}{$\mathrm{Al}_{2} \mathrm{O}_{3}$ deposition } \\
$\mathrm{CH}_{4}[$ mo1\%] & time[min] & growth rate & $\mathrm{Al}_{2} \mathrm{O}_{3}$ modification \\
\hline 3 & 5 & 3 & $0.6 \pm 0.05$ & 100 & 0 \\
3 & 10 & 3 & $0.60 \pm 0.1$ & 100 & 0 \\
6 & 5 & 6 & $0.7 \pm 0.05$ & 100 & 0 \\
6 & 10 & 6 & $0.55 \pm 0.05$ & 100 & 0 \\
\hline
\end{tabular}

"White spots" on the $\mathrm{Al}_{2} \mathrm{O}_{3}$ surface, caused by differences in the conductivity, were found. These changes seemed to be caused by the incorporation of carbon. X-Ray diffraction showed only alpha- $\mathrm{Al}_{2} \mathrm{O}_{3}$. $\mathrm{Al}_{2} \mathrm{O}_{3}$ coatings with grain sizes from 0.05 to $0,50 \mu \mathrm{m}$ were obtained. These coatings were much finer grained than the $\mathrm{Al}_{2} \mathrm{O}_{3}$ coatings deposited without $\mathrm{CH}_{4}$ addition $/ 8 /$.

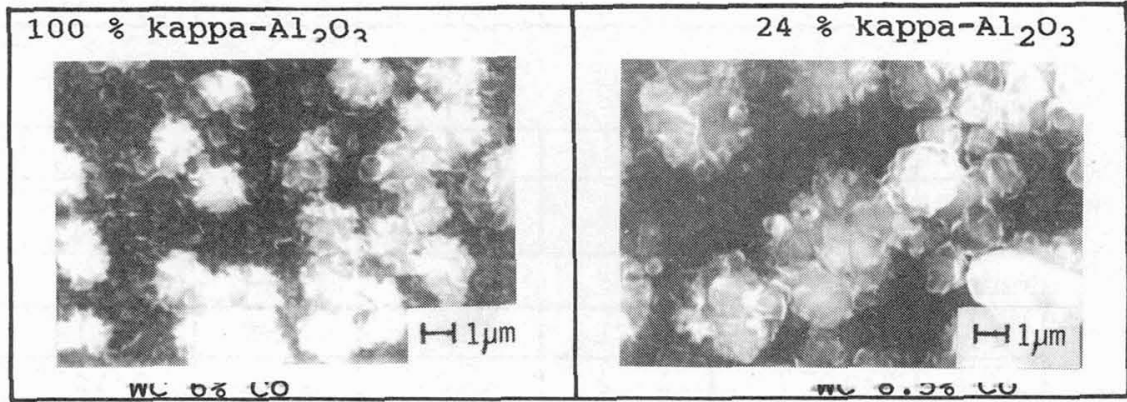

Fig.2: Influence of the Co content in WC-Co on the $\mathrm{Al}_{2} \mathrm{O}_{3}$ deposition: Tic etch treatment: 6 mol\% $\mathrm{CH}_{4} / 1 \mathrm{~min}$ (gas flow cycle 2) Temp.: $950^{\circ} \mathrm{C}$

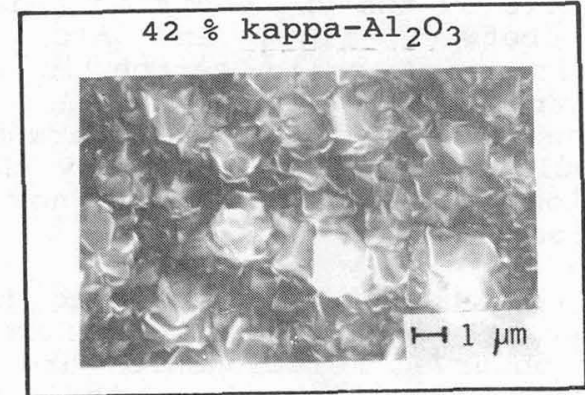

Fig.3: $\mathrm{Al}_{2} \mathrm{O}_{3}$ coating morphology; TiC etch treatment: 3 mol\% $\mathrm{CH}_{4} / 5 \mathrm{~min}$ substrate: WC $8,5 \%$ Co, Temp.: $1030^{\circ} \mathrm{C}$ (gas flow cycle 2 ) 


\section{DISCUSSION OF THE RESULTS}

As known from the literature a clean TiC underlayer is necessary to deposit kappa-Al $\mathrm{O}_{3}$. Cobalt and oxygen prevent the deposition of kappa- $\mathrm{Al}_{2} \mathrm{O}_{3}$. During the TiC etching treatment with $\mathrm{AlCl}_{3} / \mathrm{CH}_{4} / \mathrm{H}_{2}$, impurities are removed from the Tic surface, making the deposition of kappa- $\mathrm{Al}_{2} \mathrm{O}_{3}$ possible (Table 6). These "cleaning procedures" can be described by the following reactions:

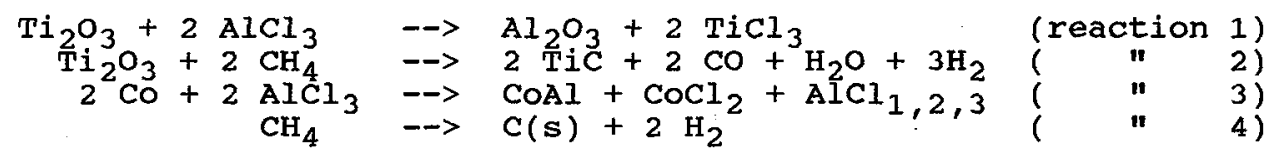

Table 6: Stable phases formed thermodynamically under experimental conditions during the Tic etching

conditions: 2 mol\% $\mathrm{AlCl}_{3} ; 3,6 \mathrm{~mol} \% \mathrm{CH}_{4}, 96 \mathrm{~mol} \% \mathrm{H}_{2}$

$950^{\circ} \mathrm{C}$

$0.1 \mathrm{~mol} \% \mathrm{Ti}_{2} \mathrm{O}_{3} ; 0.1 \mathrm{~mol} \% \mathrm{Co}$

condensed phases

\begin{tabular}{|c|l|l|l|l|l|}
\hline $\mathrm{CH}_{4}$ & $\mathrm{C}(\mathrm{s})$ & $\mathrm{Co}$ & $\mathrm{COA1}$ & $\mathrm{TiC}$ & $\mathrm{Al}_{2} \mathrm{O}_{3}$ \\
\hline 3 & 2.72 & 0.05 & 0.04 & 0.2 & 0.09 \\
6 & 5.71 & 0.04 & 0.06 & 0.2 & 0.99 \\
\hline
\end{tabular}

gaseous phases

\begin{tabular}{|c|c|c|c|c|c|}
\hline $\mathrm{CH}_{4}$ & $\mathrm{COCl}_{2}$ & $\mathrm{AlCl}_{3}$ & $\mathrm{AlCl}_{2}$ & $\mathrm{AlCl}$ & $\mathrm{TiCl}_{3}$ \\
\hline 3 & $2.6 \cdot 10^{-5}$ & 1.65 & 0.08 & 0.025 & $2.3 \cdot 10^{-5}$ \\
6 & $2.6 \cdot 10^{-5}$ & 1.64 & 0.08 & 0.03 & $2.3 \cdot 10^{-5}$ \\
\hline
\end{tabular}

$1030^{\circ} \mathrm{C}$

condensed phases

\begin{tabular}{|c|c|c|c|c|c|}
\hline $\mathrm{CH}_{4}$ & $\mathrm{C}(\mathrm{s})$ & $\mathrm{Co}$ & $\mathrm{COAl}$ & $\mathrm{TiC}$ & $\mathrm{Al}_{2} \mathrm{O}_{3}$ \\
\hline 3 & 2.7 & - & 0.09 & 0.2 & 0.09 \\
6 & 5.7 & - & 0.09 & 0.2 & 0.09 \\
\hline
\end{tabular}

gaseous phases

\begin{tabular}{|c|c|l|l|l|l|}
\hline $\mathrm{CH}_{4}$ & $\mathrm{CoCl}_{2}$ & $\mathrm{AlCl}_{3}$ & $\mathrm{AlCl}_{2}$ & $\mathrm{AlCl}$ & $\mathrm{TiCl}_{3}$ \\
\hline 3 & $3 \cdot 10^{-5}$ & 0.22 & 0.04 & 0.39 & $8 \cdot 10^{-6}$ \\
6 & $8 \cdot 10^{-5}$ & 1.45 & 0.16 & 0.1 & $3.4 \cdot 10^{-5}$ \\
\hline
\end{tabular}

These calculations indicate that $\mathrm{Ti}_{2} \mathrm{O}_{3}$ should react completely. Two different reactions are possible, one being the reduction and carburization of $\mathrm{Ti}_{2} \mathrm{O}_{3}$ to $\mathrm{TiC}$ by the $\mathrm{CH}_{4}$ addition (reaction 2) and the other one the reaction between $\mathrm{Ti}_{2} \mathrm{O}_{3}$ and $\mathrm{AlCl}_{3}$ to form $\mathrm{Al}_{2} \mathrm{O}_{3}$ (reactions 1 ). The deposition of solid carbon is thermodynamically possible at all $\mathrm{CH}_{4}$ concentrations (reaction 4 ).

Two different Co reactions are predicted by thermodynamics, a CoAl alloy and the volatile $\mathrm{COCl}_{2}$. Since the COAl alloy should have formed under all etching conditions, it apparently has no influence on the $\mathrm{Al}_{2} \mathrm{O}_{3}$ modification (reaction 3 ).

The etching parameters $\mathrm{CH}_{4}$ concentration, etching time, temperature and co concentrations strongly influenced the formation of kappa$\mathrm{Al}_{2} \mathrm{O}_{3}$. The experimentally observed relationships are reflected by the calculations given in Table 7. Fig. 4 summarizes these results. 
Table 7: Influence of the TiC etching time and $\mathrm{CH}_{4}$ concentration on the $\mathrm{Al}_{2} \mathrm{O}_{3}$ modification: no $\mathrm{CH}_{4}$ during $\mathrm{Al}_{2} \mathrm{O}_{3}$ deposition

\begin{tabular}{|c|c|c|}
\hline etching time & $\mathrm{CH}_{4}$ concentration & $\mathrm{Al}_{2} \mathrm{O}_{3}$ modification \\
\hline short & low & alpha \\
short & high & alpha-kappa \\
\hline long & low & alpha-kappa \\
long & high & alpha \\
\hline
\end{tabular}

This dependence of the kappa- $\mathrm{Al}_{2} \mathrm{O}_{3}$ formation on the etching time and $\mathrm{CH}_{4}$ concentration can be explained as follows:

Etching with high $\mathrm{CH}_{4}$ concentrations for short periods, or with low $\mathrm{CH}_{4}$ concentrations for longer periods, totally removes oxygen from the surface and no carbon is deposited. Kappa- $\mathrm{Al}_{2} \mathrm{O}_{3}$ formation becomes possible on these cleaned surfaces because of the epitaxy of TiC.

Etching times which are too long and $\mathrm{CH}_{4}$ concentrations which are too high cause the deposition of carbon, which disturbs the epitaxial nucleation of kappa- $\mathrm{Al}_{2} \mathrm{O}_{3}$ on TiC. On the other hand etching times which are too short do not remove all the $\mathrm{Ti}_{\mathrm{x}} \mathrm{O}_{\mathrm{y}}$.

Summarized, the etching parameters must be precisely controlled in order to remove all of the oxygen from the TiC underlayers but without permitting any solid carbon deposition.

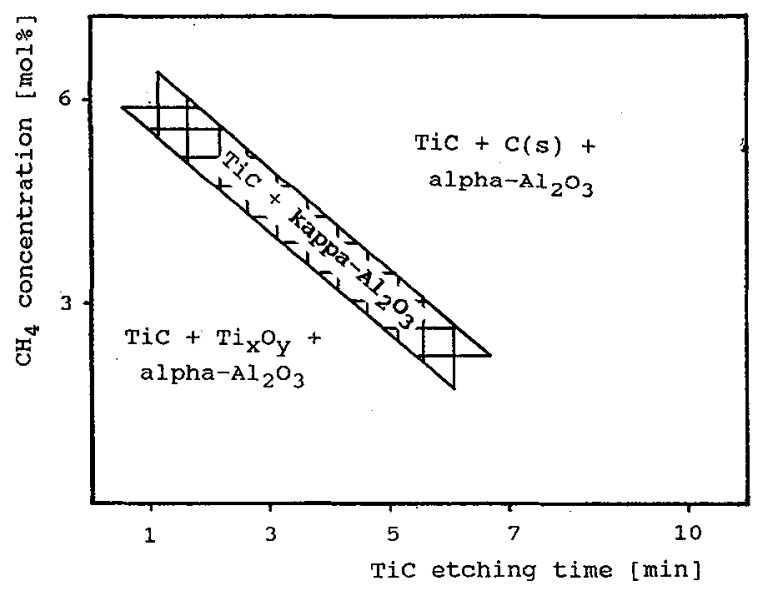

Fig.4: Influence of the $\mathrm{CH}_{4}$ concentrations and etching times on the kappa- $\mathrm{Al}_{2} \mathrm{O}_{3}$ formation

\section{CONLUSION}

TiC coatings are oxidized by air and humidity if removed after coating from the reaction chamber. In a subsequent $\mathrm{Al}_{2} \mathrm{O}_{3}$ deposition on such substrates no kappa- $\mathrm{Al}_{2} \mathrm{O}_{3}$ was formed.

The experimental results from etching the Tic underlayers with different $\mathrm{CH}_{4} / \mathrm{AlCl}_{3} / \mathrm{H}_{2}$ gas mixtures followed by the $\mathrm{Al}_{2} \mathrm{O}_{3}$ deposition without $\mathrm{CH}_{4}$ indicated different parameters which permit the preparation of an oxygen-free TiC underlayer.

The etching parameters which influenced the alpha:kappa- $\mathrm{Al}_{2} \mathrm{O}_{3}$ ratio are:

- the lower $\mathrm{CH}_{4}$ concentration during TiC etching caused longer etching times for the deposition of kappa- $\mathrm{Al}_{2} \mathrm{O}_{3}$,

- the amount of kappa- $\mathrm{Al}_{2} \mathrm{O}_{3}$ could be increased by decreasing the etching and deposition temperature, 
- the lower Co concentration led to a higher amount of kappa- $\mathrm{Al}_{2} \mathrm{O}_{3}$.

For industrial application it is important that $\mathrm{CO}_{2}$ be added at a specific interval after the $\mathrm{AlCl}_{3} / \mathrm{H}_{2}$ gas mixture is added in order to allow full coverage of the virgin TiC surface with adsorbed $\mathrm{AlCl}_{3}$. This prevents the TiC underlayers from being oxidized by $\mathrm{CO}_{2}$ and $\mathrm{H}_{2} \mathrm{O}$.

\section{ACKNOWLEDGEMENT}

The authors wish to thank SANDVIK $A B$, Stockholm, for supplying freeof-charge specimens and for financial support. Helpful discussions with Dr. Mats sjöstrand and particularly Dr. Jan Lindström are gratefully acknowledged.

\section{REFERENCES}

/1/ Saalfeld H., Matthies H., Datta S.K.: Ber.Deut.Keram.Ges. 45 (1968) 212.

12/ Okumiya M., Yamaguchi G.: Bulletin of the Chemical Society of Japan, Vol. 44 (1971) 1567.

/3/ Iler R.K.: J.Amer.Ceram.Soc. Vo1. 47, No.7, (1964) 539.

/4/ Frederiksson E., Carlsson J.0.: Proc. EURO-CVD 6 th, Perpignan (1989) C 5391.

/5/ Chatfield C., Lindström J., sjöstrand M.: Proc. EURO-CVD $6{ }^{\text {th , }}$ Perpignan, (1989) C5 377.

/6/ Colombier C., Lux B.: J. Mater. Science, 24 (1989) 462.

/7/ Vourinen S., Karlsson L.: Proc. 4th Int. Conf. on Surface Modification Techn., Paris 1990.

/8/ Danzinger M., Haubner R., Lux B.: Proc. EURO-CVD $8^{\text {th }}$, Glasgow 1991, in preparation. 